\title{
METAPHORICAL CONCEPTUALIZATIONS OF THE BODY IN PSYCHOPATOLOGY AND POETRY
}

\section{(Conceitualizações do corpo em psicopatologia e em poesia)}

\author{
Alfonso Santarpia, R. Venturini, A. Blanchet, M. Cavallo \\ (Université Vincennes-Saint-Denis - PARIS VIII)
}

\begin{abstract}
The goal of our study is to identify several conceptualizations of the body expressed in the contexts of psychopathology and literature. We propose a specific categorization of literary sentences drawing on Conceptual Metaphor Theory (Lakoff and Johnson 1980; 1999) and Context-Limited Simulation Theory (Ritchie 2003; 200; 2008). Based on corpus data, we show that in psychiatric manuals the physical body is always reasoned in metaphoric terms of the BODY-CONTAINER category, thus with a bigh degree of non-specific attributes. In psychoanalysis manuals, the body is represented by "sexual-sensual sentences" or by abstract "notions". Italian poetry offers an additional representation of the body with special focus on the organs and other body parts like "beart," hand(s)", "face", but also "blood", "chest", "arm(s)," "eye(s)","breast(s)", "bead," "flesh," "skin".

Key-words: literary construction of the body; conceptual metaphors of the body; contextlimited simulation theory; linguistic metaphors of the body; psychosomatics; representation of the body; literary sentences of the body.
\end{abstract}

Resumo: $O$ objetivo do nosso estudo é identificar diversas conceptualizações do corpo expressas em contextos da psicopatologia e literatura. Propomos uma categorização específica de sentenças literárias a partir da Teoria da Metáfora Conceitual (Lakoff e Johnson 1980, 1999) e a Teoria da Simulação do Contexto Limitado (Ritchie 2003, 2006, 2008). Com base no corpus analisado, mostramos que em manuais psiquiátricos, o corpo físico é sempre concebido em termos metafóricos envolvendo a categoria do CORPO COMO RECIPIENTE, portanto, com um alto grau de atributos não específicos. Em manuais de psicanálise, o corpo é representado por "sentenças sexuais-sensuais" ou por "noções" abstratas. A poesia italiana oferece uma representação adicional do corpo com ênfase especial nos órgãos e outras partes do corpo como "coração", "mão(s)", "face", mas também "sangue", "tórax", "braço(s)", "olho (s)", "seio(s)", "cabeça", "carne", "pele".

Palavras-chave: construção literal do corpo; metáforas conceptuais do corpo; teoria da simulação contextual-limitada; metáforas lingüísticas do corpo; psicosomática; representação do corpo; sentenças literais do corpo. 


\section{INTRODUCTION}

In the field of psychopathology and psychotherapeutic techniques, patient and therapist utterances frequently include figurative sentences regarding the body. Especially when patients tell us their experiences of "anomalous embodiment"1 (Cole, DePraz \& Gallagher 2000), they frequently include metaphors, similes, metonymies, and other figurative language focused on the body. Our experience in clinical practice provides the following examples:

- From a schizophrenia patient: "Today I am going out from my body...", "Doctor, I cut my head, because I had a fight with my roommate";

- From a patient suffering of anxiety disorder (i.e. panic attacks): "My body felt cold and my heart was racing";

- Another patient with anxiety disorder (agoraphobia) said: "My chest feels as if it was enveloped in a light sheet that protects me from an attack of invaders";

- Other patients with eating disorders recall "Generally, my body is an old building but when I listen to your voice, it becomes the Louvre museum", "My intestine feels...watches...smells", "My body is empty".

In Body Psychotherapy, there are several body-mediated therapeutic techniques which take advantage of patients' accounts and the figurative language used in their descriptions of their bodily experiences:

- Variable-induction relaxation (Sapir 1993) is based on therapeutic suggestions concerning patients' sensations and use of imagery; "I feel sick at heart and full of bitterness; I feel like my head's in a vice; my body has disappeared".

1. "Normal embodiment relies intrinsically on the continuity (the concordance - Einstimmigkeit - in Husserlian terms) of my sensitive, perceptive and affective bodily experience, which gives me my body as being familiar to me (a close friend, the friendship of which I don't need to question) and by contrast anomalous embodiment will refer to the experience and/or the activity of breaking or interrupting such a continuity" (Cole, DePraz \& Gallagher 2000). 
- La décentration (Virel et al. 1987) focuses on figurative utterances about the body. During his or her initial instructions, the therapists might say, "Imagine that you are at the tips of your toes; imagine that you are a small bubble and that, starting at your toes, you're going to slowly move up inside your body; when you arrive at the tips of your fingers, stay there, waiting; you're going to feel like little hearts are beating at the tips of your fingers; you're waiting, open to everything happening in your body".

- Ericksonian bypnosis, developed by Milton Erickson, is characterized in part by the use of indirect suggestions based on linguistic metaphors of the body: "Now this, of course, is the first step toward melting your legs [and] melting your hands" (Erickson et al. 1979; Erickson \& Rossi 1975).

Our intent is to create a categorization of patients' figurative utterances where they refer to the body (or parts thereof) in order to help therapists to understand and to construct a specific psychotherapeutic intervention on the patients' illnesses. Our categorization provides an alternative to anatomical descriptions of the body; we call this alternative a "Literary Construction of the Body" (Santarpia et al. 2006; 2008). We draw upon two specific theoretical approaches for the creation of such a categorization: Conceptual Metaphor Theory (Lakoff \& Johnson 1980; 1999) and Context-Limited Simulation Theory (Ritchie 2003; 2006; 2008).

Lakoff and Johnson (1980; 1999) have extensively presented linguistic data demonstrating that metaphors are not limited to rhetoric and poetic language, but that they are manifested much more frequently than previously thought also in everyday language, forming coherent systems by which all humans conceptualize world experiences. Such expressions as "your arguments are indefensible", "he attacked every weak point in my argument" are part of a metaphoric scenario that gives rise to a basic metaphor in people's conceptual system: ARGUMENT IS WAR.

This approach of conferring metaphors a conceptual quality more than a linguistic one is very useful for identifying general categories of conceptual

2. Following conventional notation, a linguistic metaphor is specified in text using italics, whereas a conceptual metaphor is presented using all capital letters. 
metaphors, especially in corpora (Cameron 1999; Ritchie 2008; see also Pragglejaz 2007).

Ritchie $(2003,2006,2008)$ has noted that conceptual metaphors cannot be described schematically and one of the greater constraints within the realm of identifying a metaphor is tied to the context of the utterance. Thus, he advances a Context-Limited Simulation Theory, in which he incorporates Barsalou's (1999) theory of perceptual simulators into the fields of meaning model (Ritchie 2008: 25). Secondary perceptual simulators are activated by a field of meaning proper to a metaphor vehicle (i.e. the metaphoric word or phrase). Perceptual simulators associated with a concept, and potentially activated by words and sentences connected with the concept, can be divided into primary and secondary simulators. For example the lexical item "shark":

- activates its own set of primary simulators of certain perceptions (primarily visual) and its own set of related words (cartilaginous skeleton, predator, sharp teeth, etc.);

- is frequently encountered in the speaker's own culture, and also prompts a larger set of secondary simulators of perceptions that are often associated with the animal in question;

- may activate memories of past experiences, such as of scuba-diving, scenes from old "B" movies, emotions and attitudes such as fear, terror, and even respect (Ritchie 2008: 30).

Thus, the Literary Construction of the Body is focused on the extended field of meaning, including conceptual metaphors of the body (for example, BODIES ARE HOUSES, BODIES ARE MACHINES, etc). It is characterized by a bodily narrative based on figurative utterances concerning anatomical and physiological features and conceptual metaphors of reference.

We identify a literary sentence (which include in the sentence a metaphor, simile, personification, hyperbole, imagery, metonym, etc.) as a linguistic sentence of the whole body, of body parts (bones, organs, liquids, etc.), of specific perceptions (exteroception, interoception, proprioception, introspection), of specific functions (digestion, respiration, etc.), of bodily actions (gestures, movements, etc.) associated with the abstract proprieties, actions in a virtual or fictional world, objects or attributes of dissimilar 
category, body idioms, conceptual metaphors. Moreover, a literary sentence activates secondary simulators.

The scope of our study is to identify different types of body conceptualizations expressed in the contexts of psychopathology and literature (Italian literature focused on bodily experiences). We selected psychoanalytic and psychiatric manuals and poetic works for our corpus analysis. Precisely, we argue that:

1) In psychiatric manuals, the physical body is always reasoned in metaphoric terms of the BODY-CONTAINER category, thus with a high degree of non-specific attributes;

2) In psychoanalysis manuals, the body is represented as "sexual-sensual sentences" or as abstract "notions";

3) Italian poetry, which frequently refers to the body, will offer an additional representation of the body with special focus on the organs and other body parts like "heart," hand/s", "face", but also "blood", "chest", "arm(s)," "eye(s)","breast(s)", "head," "flesh," "skin".

\section{Methodology}

We have selected a collection of 9 poets from various historical periods as our representative sample. These authors frequently refer to the body. To ensure that clinical psychopathology was represented, we have included professional manuals and classical works of Italian and French psychopathology. We searched for 80 lexical items regarding the concept of corporality and their occurrences in manuals and poetic works:

abdomen, anal, ankle(s), anus(es), arm(s), arteries, back of knee, back(s), beard(s), blood, body hair, body(-ies), breast(s), brow(s), calf/calves, capillaries, cheek(s), chest(s), clitoris, ear(s), embodiment, excrement, eye(s), eyelash(es), face(s), fecal matter, feces, finger(s), flesh, foot/feet, forehead(s), genital, hair, hand(s), head, heart(s), intestinal, intestine(s), kidney(s), knee(s), labial, leg(s), libidinal, libido, limb(s), lip(s), liver(s), lung(s), mouth, muscles, nail(s), neck(s), nipple(s), nose(s), oral, organ(s), organic, organism(s), orifice(s), penis(es), phallus, physical, saliva, shoulder(s), side(s), sigh(s), skeleton(s), skin, somatic, sperm, stomach(s), tear(s), throat(s), tongue(s), tooth/teeth, urine, uterus, vagina, vaginal, vein(s). 
We have also looked for the verb-forms, "incorporate" and "embody". Our research corpus for poetry includes nine works of Italian poetic literature (579, 469 lexical items) using LIZ 3.0 software with textual analysis capabilities (Zanichelli 1999):

- La Divina Commedia (Dante Alighieri, 1308-1321)

- Il Canzoniere (Francesco Petrarca, 1304-1374)

- Poemi Cavallereschi (Pietro Aretino, 1527)

- Gerusalemme Liberata (Torquato Tasso, 1575)

- Orlando Furioso (Ludovico Ariosto, 1516)

- Poesie (Tommaso Campanella, 1622)

- Poemi Conviviali (Giovanni Pascoli, 1904)

- Bestemmia (Pier Paolo Pasolini, 1958)

- La Presenza di Orfeo (Alda Merini, 1953)

The research corpus for psychoanalysis used includes sections entitled "anorexia nervosa" or "eating disorders" 3 in the most recent manual of Italian psychoanalysis, widely used in Italian psychoanalytic schools (e.g. Semi 1988; 1989; 8, 640 words); one traditional French psychoanalytic glossary (Laplanche \& Pontalis 1998; 195, 320 words) and one French thematic index of Freud's works (Delrieu 2001; 760, 480 words).

Research corpus for psychiatry comprises one well-known Italian manual of psychiatry and psychotherapy (Lalli 1991); sections entitled "anorexia nervosa" or "eating disorders" in five psychiatric manuals (Brusset 1987; Vindreau \& Hardy 1981; Lebovici et al. 1990; Gabbard 1995; Trattato Italiano di Psichiatria 1992; 51, 840 words); and the entire corpus of the DSM-IV (1995; 563, 953 words).

\section{ORgANIZATION OF CATEGORIES AND SUBCATEGORIES}

The organization of categories and subcategories is based on the intercategorial hierarchy of Prototype Theory. According to Rosch (Rosch et al. 1976; Mervis \& Rosch 1981), humans organize concepts present in

3. This psychiatric category, characterized by a difficult relationship between the body and its basic needs, can evoke different linguistic metaphors of the body. 
their real or possible (i.e. hypothetical, virtual) worlds in categories, thus creating taxonomies which are not "in the world", but in the minds of the individuals based on their interaction with their environment. Taxonomies of categories are organized into three levels. For example, "animal" is a superordinate level category; "dog" the basic level; and "fox terrier" the subordinate level. Figurative properties are rare at the superordinate level. At the basic level, figurative characteristics refer to general attributes, and at the subordinate level they refer to specific attributes. A basic level category is the best example of the category and is called a prototype; it is no longer an object in the world (best example of the category), but a mental image (stereotype) associated with the category.

In our research, the superordinate level metaphor will be a general category which includes category-wide attributes and features with a high degree of generality (cf. par. 3.1, BODY-CONTAINER). We propose a possible and non-exhaustive list of subcategories, which are characterized by prototypes (basic level) or specific properties (subordinate level).

\subsection{BODY-CONTAINER CATEGORY AND ITS SUBCATEGORIES}

THE BODY IS A CONTAINER (superordinate level) is a conceptual metaphor which refers to linguistic representations of the body, body parts, actions, gestures, specific perceptions and physiological functions depicted as general attributes (adjectives or verbs), which from now on will be indicated simply as BODY, that refer to the functions of: a container of spatiality (inside-outside, closed-open, over-under), protection, safety, filter, containment, constraint. From poetry "Losing himself in his body" (Merini 1993). From psychoanalysis "The sexual urge had a sexual object outside the body proper" (Laplanche \& Pontalis 1998). From psychiatry "Destructive impulses of objects on the body" (Brusset 1987). This superordinate level category can be divided into at least two subcategories:

THE BODY IS A COVERING (basic level and subordinate level) is a conceptual metaphor which refers to linguistic representations of BODY, associated with general attributes, basic or subordinate images of covering the body or the body's insides (functions of protection, safety, filter, containment, constraint). Unlike the superordinate CONTAINER, COVERING impedes free movement within the contained or covered area, thus spatiality 
is restricted and the container-cover is more adherent to the body or body parts. Plausible subordinate-level categories include lexical concepts such as clothing, veil, envelope, etc. From poetry: "Where the limbs veil the soul" (Petrarca 1998). From psychoanalysis: "The incorporation process refers explicitly to this bodily envelope" (Laplanche \& Pontalis 1998).

THE BODY IS A BUILDING (basic level and subordinate level) is a conceptual metaphor which refers to the linguistic representations of BODY, associated with general attributes, basic or subordinate images of architectonic structures (natural or artificial) that refer to the functions of: a container of spatiality (inside-outside, closed-open, over-under), protection, safety, filter, containment, constraint. From poetry: "My body is a prison" (Aretino 1999); "The body is the shelter of the soul" (Tasso 1999). From psychoanalysis: "It is a singular impulse that presides over the destruction of one's own organic dwelling" (Delrieu 2001). From psychiatry: "The body is perceived as inhabited by a bad object of maternal introjection" (Gabbard 1995).

\subsection{BODY-SUBSTANCE CATEGORY AND ITS SUBCATEGORIES}

BODY IS AN OBJECT (superordinate level) - is a conceptual metaphor which refers to linguistic representations of BODY that refer to the qualities and functions of various generic substances (general ideas of weight, fluidity, etc.) without specific imagery. From poetry: "Love wrote in my heart" (Petrarca 1998). This example expresses the vague idea of a penetrable heart and a body that one can write upon and read. This category includes at least three subcategories:

THE BODY IS AN NATURAL ELEMENT (basic level and subordinate level), which refers to BODY associated with attributes and stereotyped or more specific mental images concerning natural elements in their pure state, natural elements created by natural physical and chemical reactions, and the same used in cultural symbolism (earth, air, fire, water). From poetry: "Whose heart burned" (Petrarca 1998). From a psychiatric work: "Refusing food means making the body evanescent, which signifies the negation of one's identification with the mother" (Lalli 1991); "A heart of marble would have taken pity on him" (Petrarca 1998). 
In psychoanalysis, we have metaphoric imagery as water-uterus, genital organs-landscapes, penis-mountain, penis-rock, and excrement-gold. An example from Freud: "In its form and movements, a flame evokes the phallus in action" (Delrieu 2001).

THE BODY IS AN INSTRUMENT (basic level and subordinate level), which refers to the body or parts of the body associated with stereotyped or specific mental images of manufactured objects and substances. From a psychiatry text: "The body, used like a tool to win the individual battle" (Semi 1989). From psychoanalysis "the foot and the hair are objects that give off a strong odor and that are raised to the level of a fetish" (Delrieu, 2001). Examples from poetic works: "What wound shall be given to the white, velvety limbs?” (Pascoli 1999). From psychoanalysis: "The representation of the penis as a weapon, a sharp knife, a sword ... underlies many phobias" and other examples, penis-silver, mug-penis, vagina-bud, vagina-lock (Delrieu 2001).

\subsection{BODY-ORGANISM CATEGORY AND SUBCATEGORY}

BODY IS AN ORGANISM (superordinate level) - is a conceptual metaphor (idem) which refers to linguistic representations of the body, body parts, actions, gestures, movements, specific perceptions and physiological functions depicted as general attributes (adjectives or verbs) that represent the body in the form of general biological systems (animal or plant world).

BODY IS AN ANIMAL, (basic level and subordinate level) refers to the body or parts of the body associated with attributes and stereotyped or specific images of animals. In the poetry: "This submissive wildcat, heart of a tiger or bear" (Petrarca 1998); and from psychoanalysis, penis-bird, penis-snake, vagina-snail, and vagina-shell (Delrieu 2001).

BODY IS A PLANT (basic level and subordinate level), refers to the body or parts of the body associated with attributes and stereotyped or specific mental images from the plant world. From Poetry "My limbs did not remain there / neither green nor ripe, they are there, with me / with their blood and with their joints" (Dante 1988), "The body falls frozen, deprived of fire / Like the dying of a listless crimson flower" (Ariosto, 1998) 
or "Her limbs of oak and beech" (Pascoli 1999). From pychoanalysis: penistree, breast-fruit, penis-mushroom, vagina-flower, vagina-garden, pubic hair-forest (Delrieu 2001).

\subsection{BODY-SYNAESTHESIA CATEGORY}

This category is a field of meaning (Ritchie 2003; 2006; 2008) in which the body or parts of the body are associated (through metonymy process and secondary simulators) or crossed with specific functions, such as hearing and vision, or with parts of the body: "Here, in life's last light, your body still breathes" (Pasolini 1996). From psychoanalysis: "The foot fetish relates to the woman's absent penis" (Delrieu 2000); and "The concepts of excrement and penis are easily interchangeable" (Delrieu 2001).

\subsection{BODY-METAMORPHOSIS CATEGORY}

This category is a field of meaning (Ritchie 2003; 2006; 2008) in which the body or parts of the body are objectively transformed into substances, animals, etc., or experienced by the patient as perceptual bodily transformations (bodily hallucinations in modified states of consciousness or into a psychotic state) in real time. From poetry: "See Tiréslas, / who changed from male to female, / bit by bit" (Ariosto 1998). Examples from Freud: "He thinks that the two sexes have the same genital organ, the male organ" (Delrieu 2001); and "Incorporation, a process in which the subject places and keeps an object inside the body in a more or less fantastical manner" (Laplanche \& Pontalis 1998). From psychiatric texts, probably influenced by the psychoanalytic model: "the fantasy of incorporation" (Brusset 1987), "the bulimic patient symbolically destroys and incorporates people" (Gabbard 1995).

\subsection{BODY-DIVINE CATEGORY AND SUBCATEGORIES}

THE BODY IS DIVINE (superordinate level) - is a conceptual metaphor which refers to linguistic representations of the body, body parts, actions, gestures, movements, specific perceptions and physiological 
functions depicted as general and undetermined (adjectives or verbs) of divine, supernatural and sacred attributes (lightness, brightness, clearness, immortality) etc.). From Psychiatry "Anorexics want a subtle body, without flesh" (Trattato Italiano di Psichiatria 1992) or "her immortal body," "the ideal body," and "a body without flesh" (Semi 1989).

This category includes two subcategories:

THE BODY IS SUPERNATURAL Body-Supernatural (basic level and subordinate level), which refers to the body or parts of the body associated with attributes and stereotyped or specific mental images of supernatural and divine creatures (angles, gods, diabolic creatures, mythological animals). From poetry "Truly, like an angel in a human body" (Aretino 1999), "May your heart conquer, in its great triumph, / extraordinary angel (Petrarca 1998) or "She showed who, in all his grace, / Resembled the god Mars, except for his face" (Ariosto 1998). (this and the metaphor suggested above do not follow the traditional $\mathrm{X}$ is $\mathrm{Y}$ metaphor as, in this case, $\mathrm{Y}$ is a predicative adjective, the complement of a copulative function that links it to the noun)

BODY IS A SACRED OBJECT (basic level and subordinate level): the body or parts of the body are associated with attributes and stereotyped or specific mental images of sacred and supernatural objects. From psychiatry "In a perverse relationship, the body becomes a sacred fetish offered to another to deny the laws of nature" (Trattato Italiano di Psichiatria 1992). From Poetry "Your flesh is bread, your blood is wine" (Pascoli 1999).

\subsection{BODY-ABSTRACT CATEGORY}

This category is a field of meaning (Ritchie 2003; 2006; 2008) in which the body or bodily parts are associated with abstract concepts, characterized by the absence of figurative properties related to natural or biological elements. These metaphors require in-depth interpretation, from poetry: "I offered you my body as a movement of happy sadness" (Merini 1993), "Freedom returns / and the flesh is a pure sound" (Pasolini 1996). Psychiatry texts talk about the body-place: "The subject's relationship with his/her own body ... the preferred place for conflicts" (Brusset 1987). In addition, psychoanalysis discusses the idea of a body-source or body-zone 
- for example, "In anorexia, the negation of the body's representation as a source of pleasure" (Semi 1988) and "Every part of the body can become an erogenous zone (Delrieu 2001).

\section{RESULTS}

Table 1: Frequency and categories of conceptual metaphors and the fields of meaning

\begin{tabular}{|c|c|c|c|}
\hline Categories & Psychonalaysis & Psychiatry & Poetry \\
\hline BODY-CONTAINER & f $81 ; 23$ typ $\quad(12 \mathrm{~g}, 11 \mathrm{~s})$ & f 40; 10 typ $(10 \mathrm{~g})$ & f 384;31 typ (25g, 6s) \\
\hline BODY-SUBSTANCE & f $123 ; 76$ typ $(12 \mathrm{~g}, 60 \mathrm{~s}, 4 \mathrm{sp})$ & f $3 ; 2 \operatorname{typ}(1 \mathrm{~g}, 1 \mathrm{~s})$ & f $121 ; 95$ typ $(51 \mathrm{~g}, 44 \mathrm{~s})$ \\
\hline BODY-BIOLOGICAL & f 29; 14typ (1g, 13s) & 0 & f $28 ; 25 \operatorname{typ}(6 g, 12 s, 7 s p)$ \\
\hline $\begin{array}{l}\text { BODY- } \\
\text { SYNAESTESIA }\end{array}$ & f $37 ; 10 \operatorname{typ}(10 \mathrm{~g})$ & 0 & f 35; 16typ (16g) \\
\hline BODY-METAMOR. & f 58; 11 typ $(7 \mathrm{~g}, 4 \mathrm{~s})$ & 0 & f $40,29 \operatorname{typ}(6 \mathrm{~g}, 18 \mathrm{~s}, 5 \mathrm{sp})$ \\
\hline BODY-DIVINE & f $7 ; 7 \operatorname{typ}(7 \mathrm{~g})$ & f $2 ; 1$ typ $(1 \mathrm{~g})$ & f $10 ; 9$ typ $(4 \mathrm{~g}, 4 \mathrm{~s}, 1 \mathrm{sp})$ \\
\hline BODY-ABSTRACT & f 190; 67typ (67 g) & f $8 ; 5$ typ $(5 g)$ & f $80 ; 65$ typ $(65 \mathrm{~g})$ \\
\hline
\end{tabular}

Table 2: Frequency and types of sentences focus on various organs and bodily substances

\begin{tabular}{|c|c|c|c|}
\hline Organs & Psychoanalysis & Psychiatry & Poetry \\
\hline generic body & f $188 ; 79$ typ (59a, 20 b) & f $52,10 \operatorname{typ}(9 a, 1 b)$ & f $176 ; 55$ typ (22a, 30b, 3c) \\
\hline Vagina & f 62; 31typ (7a, 23b, 1c) & 0 & 0 \\
\hline genital organ & f $26 ; 11$ typ $(6 a, 5 b)$ & 0 & 0 \\
\hline Mouth & f 39; 10typ (10a) & 0 & f 27; $3 \operatorname{typ}(2 a, 1 b)$ \\
\hline bodily orifice & f $11 ; 8 \operatorname{typ}(6 a, 2 b)$ & 0 & 0 \\
\hline Uterus & f 10; 4typ (4b) & 0 & 0 \\
\hline Penis & f 91; 43typ $(16 \mathrm{a}, 24 \mathrm{~b}, 3 \mathrm{c})$ & 0 & 0 \\
\hline Phallus & f $23 ; 6 \operatorname{typ}(5 a, 1 b)$ & 0 & 0 \\
\hline Anus & f $38 ; 7$ typ (7a) & 0 & 0 \\
\hline
\end{tabular}

Table 3: Frequency and types of metaphors focus on various organs and bodily substances

\begin{tabular}{|l|c|c|c|}
\hline Organs & Psychoanalysis & Psychiatry & Poetry \\
\hline Blood & 0 & 0 & $\mathrm{f} 19 ; 10$ typ $(7 \mathrm{~g}, 3 \mathrm{~s})$ \\
\hline Chest & 0 & 0 & $\mathrm{f} 21 ; 5$ typ $(4 \mathrm{~g}, 1 \mathrm{~s})$ \\
\hline arm/s & 0 & 0 & $\mathrm{f} 12 ; 7$ typ $(5 \mathrm{~g}, 2 \mathrm{~s})$ \\
\hline eye/s & 0 & 0 & $\mathrm{f} 39 ; 25$ typ $(13 \mathrm{~g}, 12 \mathrm{~s})$ \\
\hline
\end{tabular}




\begin{tabular}{|l|c|c|c|}
\hline breast/s & $\mathrm{f} 1 ; 1$ typ (1a) & 0 & $\mathrm{f} 14 ; 5$ typ (5g) \\
\hline Face & 0 & 0 & $\mathrm{f} 47 ; 7$ typ (3g, 3s, 1sp)) \\
\hline Head & 0 & $\mathrm{f} 1 ; 1$ typ (1a) & $\mathrm{f} 16 ; 4$ typ $(2 \mathrm{~g}, 2 \mathrm{~s})$ \\
\hline Heart & 0 & 0 & $\mathrm{f} 158 ; 58$ typ $(41 \mathrm{~g}, 14 \mathrm{~s}, 3 \mathrm{sp})$ \\
\hline Skin & 0 & 0 & $\mathrm{f} 11 ; 8$ typ $(6 \mathrm{~g}, 1 \mathrm{~s}, 1 \mathrm{sp})$ \\
\hline hand/s & $\mathrm{f} 1 ; 1$ typ ((1a) & 0 & $\mathrm{f} 87 ; 5$ typ $(4 \mathrm{~g}, 1 \mathrm{~s})$ \\
\hline Flesh & 0 & 0 & $\mathrm{f} 21 ; 14$ typ $(9 \mathrm{~g}, 5 \mathrm{~s})$ \\
\hline
\end{tabular}

Key

typ $=$ types of sentences;

$g=$ sentences without attributes;

$s=$ stereotyped sentences;

$s p=$ sentences with specific attributes;

$f=$ frequency of the sentences;

genital organs = generic genital organs;

generic body = generic metaphors of the body;

$f=$ frequency of the metaphors.

Metamor $=$ Metamorphic.

\section{Discussion AND CONCLUSION}

The analysis of psychiatric and psychoanalytic manuals and works of poetic literature show differences in the use of conceptual metaphors in these respective discourses. In psychiatric manuals, the physical body is always reasoned in metaphoric terms of the BODY-CONTAINER category, thus with a high degree of non-specific attributes. In psychoanalysis manuals, the body is represented as "sexual-sensual sentences" or as abstract "notions": linguistic metaphors of the body on the following terms: "genital organs," "mouth," "uterus," "penis," "phallus," “anus," "vagina," and "body orifice." Italian poetry offers an additional representation of the body with special focus on the organs and other body parts like "heart," hand/s", "face", but also "blood", "chest", "arm(s)," "eye(s)", "breast(s)", "head," "flesh," "skin", "hand(s)," and "tongue." Poetry offers us the opportunity to create, deepen and reconstruct emotional experiences through the richness of metaphorical thought. With the growth of the neurosciences, poetic thought could serve as an important resource in the conceptualization of the body.

We have created a figurative categorization of the bodily sentences in order to help therapists understand and construct specific psychotherapeutic intervention on the patient disease. Our categorization will provide an alternative to the anatomical description of the body; we call this alternative a Literary Construction of the Body (Santarpia et al. 2006; 2008). 
Conceptual Metaphor Theory (Lakoff and Johnson 1980; 1999) and Context-Limited Simulation Theory (Ritchie 2003; 2006; 2008) can help the psychologists and psychotherapists to categorize and to understand literary sentences in the clinical context. In future researches we want to analyze the patient's agency/subjectivity in relation to the body, or body parts $(\mathrm{B} / \mathrm{BP})$ :

1) The person acts on the $\mathrm{B} / \mathrm{BP}$;

2) The $\mathrm{B} / \mathrm{BP}$ acts on the patient;

3) There is no action; patient and B/BP are simply "there" and acknowledged.

\section{EXPERIMENTAL PERSPECTIVES}

These studies aim at elaborating an electrophysiological instrument called ABLASMI (Santarpia et al. press; Santarpia 2007). It is an instrument grounded on 8 protocols that have been recorded on CDRom by a French actor. The protocols have been organized in accordance with the BODY IS A SUBSTANCE conceptual metaphor and the idea of perspective. We examined influence of repetition of weight-related sentences on the involuntary pressure forces of the forearms, when in a relaxed state. These forces were involuntary oscillations, exerted by muscle movements of the breathing-cycle and muscle movements of the arm on force sensors. In order to gather the data, we constructed a linguistic bio-mechanic system (Ablasmi), which has one relaxation armchair with a system of 2 force sensors specifically designed to be sensitive to pressure forces of each forearm when the subjects listened to the specific recorded weight-related sentences.

In this experiment we used some classical sentences such as "your right/left arm is heavy" inspired by Autogenic Training (Schultz 1974) and some sentences, such as "your right/left arm is made of lead", inspired by Grossmann's relaxation technique. We observed that when the recorded sentences were directed to the right arm there was a significant increase of involuntary pressure forces on the right forearm. Additionally, we observed the same effect on the left forearm for the sentences directed to the left forearm. We had an experimental evidence of a definite linguistic 
effect of weight-related sentences on the involuntary pressure forces of the forearms.

Recebido em setembro de 2009

Aprovado em fevereiro de 2010

E-mails: asantarpia@yahoo.it ricsabazio@libero.it blanchet@univ-paris8.fr cavallomi@libero.it

\section{REFERENCES}

Aretino Pietro. 1999. Poemi Cavallereschi. (Trans. ed. Vol.) Bologna: Letteratura Italiana Zanichelli in 6 C.D. ROM.

Arioste, Ludovico, Roland Furieux. 2000. Traduction de Michel Orcel. Paris: Le Seuil.

Barsalou, Lawrence. 1999. Perceptual symbol systems. Behavioral and Brain Science, 22, 577-660.

BRusset, Bernard. 1987. Encyclopédie Médico-Chirurgicale: Valeur sémiologique des anomalies des conduites alimentaires,37-144-A: 4. (Trans. ed.) Paris: Elsevier.

CAMERON $_{2}$ Lynne. 1999. Identifying and describing metaphor in spoken discourse data. In L. Cameron \& G. Low. (Eds.) Researching and Applying Metaphor, Cambridge: Cambridge University Press.

Cole, Jonathan, Natalie Depraz, Shaun Gallagher, 2000 Unity and Disunity in Bodily Awareness: Phenomenology and Neuroscience. Available at < http:// pegasus.cc.ucf.edu/ gallaghr/brus3.html $>$ ).

Delrieu, Alain. 2001. Sigmund Freud. Index Thématique, 2 (Trans. ed.) Paris: Anthropos.

DSMIV. 1995. DSMIV. (Trans. ed. Traduction italienne) Milano: Masson.

Erickson, Milton \& Ernest Rossi. 1975. Varieties of Double Bind. American Journal of Clinical Hypnosis, 17, 143-57.

, Ernest Rossi \& Sheila Rossi. 1979. Tecniche di Suggestione Ipnotica. (Trans. ed.) Roma: Astrolabio.

GabBard, Glen. 1995. Psichiatria Psicodinamica. (Trans. ed.) Milano: Raffaele Cortina, Editor.

Group Pragglejaz. 2007. MIP: A Method for Identifying Metaphorically Used Words in Discourse. Metaphor and Symbol. 22, 1-39. 
Lakoff, George \& Mark Johnson. 1980. Metaphors we live by. Chicago: University of Chicago Press. . 1999. Philosophy in the Flesh. (Trans. ed. Vol.) New York: Basic Books.

Lalli, Nicola. 1991. Manuale di Psichiatria e Psicoterapia. (Trans. ed.) Napoli: Liguori

Laplanche, Jean \& Jean-Betrand Pontalis 1998. Vocabulaire de la Psychanalyse. (Trans. 2 ed.) Paris: PUF.

Merini, Alda. 1993. La Presenza di Orfeo (Tu sei Pietro. Paura di Dio. Lapresenza di Orfeo. Nozze Romane). (Trans. ed.) Milano: Libri Scheiwiller.

Mervis, Carolyn \& Eleonor Rosch. 1981. Categorization of natural objects. Annual Review of Psychology. 32, 89-115.

Pascoli, Giovanni. 1999. Poemi Conviviali. Letteratura Italiana Zanichelli in 6 CD ROM. 1999. Bologna: Zanichelli.

Petrarca, Francesco. 1988. Le Chansonnier. Traduction de Pierre Blanc \& Gérard Genot.Paris: Bordas.

RITCHIE, David. 2003. "ARGUMENT IS WAR" - Or is it a game of chess? Multiple meanings in the analysis of implicit metaphors. Metaphor and Symbol, 18, 125-46.

.2004. Metaphors in conversational context: Toward a connectivity theory of metaphor interpretation. Metaphor and Symbol. 19, 265-87. 2006. Context and Connection in Metaphor. (Trans. ed.) Basingstoke England: Palgrave Macmillan, Ltd.

. 2008. Gateshead Revisited: Perceptual Simulators and Fields of Meaning in the Analysis of Metaphors. Metaphor and Symbol. 23, 24-49.

Rosch, Eleanor, Carolyn Mervis, Wayne Gray, David Johnson \& Penny Boyes-Braem. 1976. Objects in Natural Categories. Cognitive Psychology. 8, 382-439.

Santarpia, Alfonso, Alain Blanchet, Jean-François F Lambert, Riccardo Venturini, Michele Cavallo \& Giuseppe Mininni. 2006. PerceptiveLiterary Construction of the body in clinical psychology. In R. Trappl. (Ed.) Cybernetics and Systems 2006, 2, 381-86. Wien.

, Riccardo Venturini, Alain Blanchet, Michele Cavallo, Giuseppe Mininni \& Jean-François LAmbert. 2008. Elementi della costruzione percettivo-letteraria. In C. Casadio. (Ed.) Le vie della metafora: linguistica, filosofia, psicologia, 195-224. Sulmona: Edizioni Prime Vie. 
.2007. L'Influence du langage métaphorique sur le corps dans un contexte de relaxation. Phd Dissertation. Université Paris 8 , Paris.

, Alain Blanchet, Giuseppe Mininni, Fabrice KwiatKowski, Lisa Lindeman \& Jean François Lambert. Press. The «weight» of words on the forearms during the relaxation. Applied Psychophysiology and Biofeedback.

SAPIR, Michel. 1993. La relaxation à inductions variables. (Trans. ed.) Grenoble: La Pensée sauvage.

Semi, Antonio Alberto. 1988. Trattato di Psicoanalisi: Teoria e Tecnica, 1. (Trans. ed.) Milano: Raffaele Cortina Editor.

1989. Trattato di Psicoanalisi: Clinica, 2. (Trans. ed.) Milano: Raffaele Cortina Editor.

Serge Lebovici, René Diatkine \& Michel Soulè. 1990. Trattato di Psichiatria dell'infanzia e dell'adolescenza. (Trans. ed. Vol. 2.) Roma: Borla.

Tommaso Campanella. 1999. Poesie. Letteratura Italiana Zanichelli in 6 C.D. A cura du Stoppelli P, Picchi E. Bologna : Zanichelli.

Torquato TAsso. 1999. Aminta At.3. Gerusalemme Liberata. (Trans. ed. Vol.) Bologna: Letteratura Italiana Zanichelli in 6 CD ROM.

Trattato Italiano di Psichiatria. 1992. Trattato Italiano di Psichiatria, 1, 2, 3. (Trans. ed.) Milano-Parigi-Barcellona-Bonn: Masson.

Vindreau, Christine \& Patrick Hardy. 1981. Encyclopédie Médico-Chirurgicale: Les conduites boulimiques. (Trans. ed. Vol. Psychiatrie. 37-105-D-10; 5-6.) Paris: Elsevier.

Virel, André, Jean-François Lambert \& Odile Dorkel. 1987. La Decentration. (Trans. ed. Tome I.) Paris: Harmattan.

ZANICHELLI. 1999. LIZ-Letteratura Italiana in 6 CD ROM (Version 3.0). Roma: Zani. 